\title{
Diet plus insulin compared to diet alone in the treatment of gestational diabetes mellitus: a systematic review
}

F.M.A. Giuffrida ${ }^{1}$, A.A. Castro ${ }^{2}$, A.N. Atallah ${ }^{2}$ and S.A. Dib ${ }^{1}$
${ }^{1}$ Divisão de Endocrinologia e Metabolismo, and ${ }^{2}$ Centro Cochrane do Brasil, Departamento de Medicina, Escola Paulista de Medicina, Universidade Federal de São Paulo, São Paulo, SP, Brasil

\section{Correspondence}

F.M.A. Giuffrida

R. Botucatu, 740

2 o andar

04034-970 São Paulo, SP

Brasil

Fax: +55-11-5579-6636

E-mail: fernandogiuffrida@uol.com.br or fernandogiuffrida@hotmail.com

Publication supported by FAPESP. $\ldots \ldots \ldots \ldots \ldots \ldots$

Received August 29, 2002 Accepted June 17, 2003

\begin{abstract}
Fetuses of mothers with gestational diabetes mellitus are at increased risk to develop perinatal complications mainly due to macrosomia. However, in view of the marked heterogeneity of this disease, it seems difficult to set guidelines for diagnosis and treatment. This complicates the choice of assigning patients either to diet or to insulin therapy. Also of concern is how much benefit could be expected from insulin therapy in preventing fetal complications in these patients. In a systematic review of the literature assessing the efficacy of insulin in preventing macrosomia in fetuses of mothers with gestational diabetes, we found six randomized controlled trials comparing diet alone to diet plus insulin. The studies included a total of 1281 patients (644 in the diet plus insulin group and 637 in the diet group), with marked differences among trials concerning diagnostic criteria, randomization process and treatment goals. Meta-analysis of the data resulted in a risk difference of -0.098 ( $95 \% \mathrm{CI}$ : -0.168 to -0.028$)$, and a numbernecessary-to-treat of $11(95 \% \mathrm{CI}$ : 6 to 36$)$, which means that it is necessary to treat 11 patients with insulin to prevent one case of macrosomia. This indicates a potential benefit of insulin, but not significantly enough to set treatment guidelines. Because of the heterogeneous evidence available in the literature about this matter, we conclude that larger trials addressing the efficacy of these two therapeutic modalities in preventing macrosomia are warranted.
\end{abstract}

Gestational diabetes mellitus (GDM) is defined as carbohydrate intolerance with onset or first recognition during pregnancy showing a marked heterogeneity in terms of the diagnostic and therapeutic approaches. There is a wide variety of diagnostic criteria regarding glucose challenge doses and glycemic thresholds (1). Moreover, fetuses of women with GDM are at increased risk for perinatal morbidity and mortality, and their
Key words

- Diabetes

- Gestational

- Diet therapy

- Fetal macrosomia

- Insulin

- Meta-analysis ..................... relationship with maternal glycemic control is more likely to be a continuum rather than a dichotomous parameter measurable in a satisfactory way by setting a threshold. There also seems to be great difficulty in establishing therapeutic guidelines for such a heterogeneous disease. There is no consensus about the most effective criterion to be used when shifting patients from diet alone to insulin therapy plus diet. The current recommenda- 
tions of the American Diabetes Association for GDM treatment (2) state that insulin treatment should be initiated if diet therapy fails to maintain plasma glucose values equal to or lower than $5.8,8.6$ and $7.2 \mathrm{mmol} / \mathrm{l}$ under fasting conditions and 1 and $2 \mathrm{~h}$ after meals, respectively. However, these values are based on observational and retrospective studies correlating glycemic levels and birth weight, without assessing the impact of therapeutic measures in a randomized and controlled fashion. Even oral hypoglycemic agents may have effects similar to those of insulin in the treatment of GDM (3). Moreover, the relationship between insulin treatment alone and the incidence of perinatal complications is unclear.

We performed a systematic review of randomized controlled trials (RCTs) to assess the influence of the treatment of GDM with diet plus insulin in comparison with diet alone on the occurrence of fetal macrosomia. We also assessed secondary outcomes such as birth weight (as a numerical parameter), hypoglycemia, hypocalcemia, hyperbilirubinemia, respiratory distress and

Table 1. Randomized controlled trials carried out to determine the occurrence of macrosomia in fetuses from mothers with gestational diabetes treated by diet alone or diet plus insulin.

\begin{tabular}{|c|c|c|c|c|c|c|}
\hline & \multicolumn{6}{|c|}{ Randomized controlled trial (reference number) } \\
\hline & $\begin{array}{l}\text { Coustan and } \\
\text { Lewis (5) }\end{array}$ & $\begin{array}{l}\text { O'Sullivan and } \\
\text { Mahan (6) }\end{array}$ & $\begin{array}{l}\text { Persson } \\
\text { et al. (7) }\end{array}$ & $\begin{array}{l}\text { Thompson } \\
\text { et al. (8) }\end{array}$ & $\begin{array}{l}\text { Buchanan } \\
\text { et al. (9) }\end{array}$ & $\begin{array}{l}\text { Garner } \\
\text { et al. (10) }\end{array}$ \\
\hline Randomization & ND & ND & Stratified selection & Computer generatec & ND & ND \\
\hline N & 38 & 615 & 202 & 68 & 59 & 299 \\
\hline $\begin{array}{l}\text { Treatment group } \\
\text { (macrosomic newborns observed) }\end{array}$ & $27(2)$ & $307(16)$ & $97(11)$ & $34(2)$ & $30(4)$ & $149(24)$ \\
\hline $\begin{array}{l}\text { Control group } \\
\text { (macrosomic newborns observed) }\end{array}$ & $11(4)$ & $308(41)$ & $105(14)$ & $34(9)$ & $29(13)$ & $150(28)$ \\
\hline $\begin{array}{l}\text { Diagnostic criterion - OGTT } \\
\text { (fasting/1 h/2 h) (mM/l) }\end{array}$ & $5.3 / 10 / 8.6$ & $6.1 / 9.4 / 6.6$ & $A \cup C$ & $\begin{array}{l}5.8 / 10.5 / 9.1 \\
\text { (NDDG) }\end{array}$ & $5.8 /-/ 6.6$ & $-/ 8 /-$ \\
\hline Macrosomia criterion & $3.864 \mathrm{~kg}$ & $4.09 \mathrm{~kg}$ & LGA (>90\%) & $4 \mathrm{~kg}$ & LGA (>90\%) & $4 \mathrm{~kg}$ \\
\hline $\begin{array}{l}\text { Treatment goals } \\
\text { (fasting/1 } \mathrm{h} \text { after meals/2 } \mathrm{h} \text { after me } \\
(\mathrm{mM} / \mathrm{l})\end{array}$ & neals) & ND & $5 / 6.5 /-$ & $5.8 /-/ 6.6$ & $3.3-4.4 /-/ 6.1$ & $4.4 / 7.7 /-$ \\
\hline Age (diet/diet + insulin) & $\begin{array}{l}2 \text { patients }>25 \text { years } / \\
15 \text { patients }>25 \text { years }\end{array}$ & ND & $\begin{array}{l}29(18-46) / \\
30.5(16-42)\end{array}$ & $\begin{array}{l}26 \pm 5.7 / \\
27 \pm 5.4\end{array}$ & $\begin{array}{l}30.3 \pm 1.1 / \\
32.4 \pm 1.0\end{array}$ & $\begin{array}{l}30.7 \pm 4.6 / \\
30.7 \pm 4.8\end{array}$ \\
\hline Obesity (diet/diet + insulin) & $5(45 \%) / 14(52 \%)$ & ND & $22 / 30$ & $\begin{array}{l}40 \% / 38 \% \\
\text { (>200 lbs) }\end{array}$ & ND & ND \\
\hline $\begin{array}{l}\text { Insulin type and } \\
\text { initial dose }\end{array}$ & $\begin{array}{c}20 \cup N P H+ \\
10 \cup R \\
\text { in the morning }\end{array}$ & $10 \mathrm{UNPH}$ & 8-12 U (NPH or R) & $\begin{array}{c}20 \cup \mathrm{NPH}+ \\
10 \cup \mathrm{R} \\
\text { in the morning }\end{array}$ & $\begin{array}{c}1.2 \mathrm{U} / \mathrm{kg} \\
(2 / 3 \text { before } \\
\text { breakfast }+ \\
1 / 3 \text { before dinner) }\end{array}$ & $\begin{array}{l}\mathrm{NPH} \text { and } \mathrm{R} \\
\text { (dosage ND) }\end{array}$ \\
\hline $\begin{array}{l}\text { Calories (kcal) in diet } \\
\text { (\% carbohydrate/protein/fat) }\end{array}$ & $\begin{array}{l}30-35 \mathrm{kcal} / \mathrm{kg} \\
(125 \mathrm{~g} \text { protein) }\end{array}$ & $\begin{array}{c}30 \mathrm{kcal} / \mathrm{kg} \\
(40 / 1.5-2 \mathrm{~g} / \mathrm{ND})\end{array}$ & $\begin{array}{c}N D \\
(50 / 20 / 30)\end{array}$ & $\begin{array}{l}35 \mathrm{kcal} / \mathrm{kg} \\
(50 / 20 / 30)\end{array}$ & $\begin{array}{l}30 \mathrm{kcal} / \mathrm{kg} \\
\text { ideal body weight) } \\
\text { and } 25 \mathrm{kcal} / \mathrm{kg} \\
\text { (above ideal) } \\
\text { (50-55/15-20/ND) }\end{array}$ & $\begin{array}{c}35 \mathrm{kcal} / \mathrm{kg} \\
(\% \mathrm{ND})\end{array}$ \\
\hline
\end{tabular}

$\mathrm{AUC}=$ area under the curve; $\mathrm{LGA}=$ large for gestational age $; \mathrm{ND}=$ not described; NDDG = National Diabetes Data Group; OGTT = oral glucose tolerance test. 
congenital malformations. We surveyed the Cochrane Controlled Trials Register, Medline, and Lilacs, as well as reference lists of trials for RCTs published in English, Spanish or Portuguese using the term "diabetes, gestational" combined with the strategy provided in the Cochrane Reviewers' Handbook (4), from 1972 to December 2001. The trials retrieved were selected by reading their abstracts or the entire trial when necessary. This review used RCTs that compared diet alone with diet plus insulin in pregnant women with GDM, regardless of randomization method or diagnostic criterion. Our primary goal was to determine the incidence of fetal macrosomia.

Of the 476 trials using this search strategy, only six (5-10) were RCTs which compared diet alone to diet plus insulin in the treatment of GDM and contained information about macrosomia (Table 1). We excluded RCTs performing the same interventions but with no information about the desired outcomes, RCTs performing other interventions and studies that were not RCTs.

The total number of patients reviewed was 1281. For macrosomia, risk difference,
Petto odds ratio, odds ratio and relative risk analyses favored treatment. Risk difference was -0.098 (95\%CI: -0.168 to -0.028$)$ and number-necessary-to-treat was $11(95 \% \mathrm{CI}$ : 6 to 36; Table 2). Other fetal complications of GDM such as hypoglycemia, hypocalcemia, hyperbilirubinemia and congenital malformations showed no statistically significant differences between the two groups.

The results obtained in this review of the literature show the potential benefit of insulin plus diet for the treatment of GDM in decreasing the incidence of macrosomia compared to diet alone. Nevertheless, methodological problems such as small samples and inadequately described randomization should be solved in larger trials with more adequate randomization and blinding. The external validity of the trials was also impaired by discrepancies involving diagnostic criteria, initial characteristics of patients and definition of the outcomes reviewed. The heterogeneity of these trials impaired the statistical quality of the conclusions of this review.

We conclude that although this review indicates a trend in favor of insulin treatment, this trend is not strong enough to

Table 2. Meta-analysis of effects of insulin treatment on the incidence of macrosomia in the included randomized controlled trials.

\begin{tabular}{|c|c|c|c|c|c|c|}
\hline $\begin{array}{l}\text { Randomized } \\
\text { controlled trial }\end{array}$ & $\begin{array}{l}\text { Experimental } \\
(\mathrm{n} / \mathrm{N})\end{array}$ & $\begin{array}{l}\text { Control } \\
(\mathrm{n} / \mathrm{N})\end{array}$ & $\begin{array}{l}\text { Weight } \\
(\%)\end{array}$ & $\begin{array}{l}\text { Risk difference } \\
(95 \% \mathrm{Cl} \text { random) }\end{array}$ & $\begin{array}{l}\text { Risk difference } \\
(95 \% \mathrm{Cl} \text { random) }\end{array}$ & \\
\hline Buchanan et al. (9) & $4 / 30$ & $13 / 29$ & 8.0 & $-0.315(-0.533,-0.097)$ & $=1$ & \\
\hline Coustan and Lewis (5) & $2 / 27$ & $4 / 11$ & 4.7 & $-0.290(-0.591,0.011)$ & & \\
\hline Garner et al. (10) & $24 / 149$ & $28 / 150$ & 23.0 & $-0.026(-0.111,0.060)$ & - & \\
\hline O'Sullivan and Mahan (6) & $16 / 307$ & $41 / 308$ & 30.5 & $-0.081(-0.126,-0.036)$ & $=$ & \\
\hline Persson et al. (7) & $11 / 97$ & $14 / 105$ & 22.1 & $-0.020(-0.111,0.071)$ & 1 & \\
\hline Thompson et al. (8) & $2 / 34$ & $9 / 34$ & 11.7 & $-0.206(-0.374,-0.038)$ & -1 & \\
\hline \multicolumn{7}{|c|}{ Chi-square 11.73 (d.f. = 5) $Z=2.73$} \\
\hline & & & & & 0 & $\begin{array}{c}1 \\
\text { Favors } \\
\text { control }\end{array}$ \\
\hline
\end{tabular}

Comparison: diet vs diet + insulin. Outcome: macrosomia.

$\mathrm{Cl}=$ confidence interval; $\mathrm{n}=$ number of macrosomic newborns observed; $\mathrm{N}=$ number of individuals treated in each group. 
modify current clinical practice. It was not possible to set guidelines for the treatment of GDM, not only because of the heterogeneity of the trials reviewed, but also because of the heterogeneity in the definition of GDM itself. Moreover, the tendency to treat each case individually is inherent to the treatment of diabetes, further preventing a standardized approach. New RCTs with larger samples and following current diagnostic criteria (2) are necessary to answer these questions.

\section{References}

1. Coustan DR (1995). Diagnosis of gestational diabetes. Are new criteira needed? Diabetes Reviews, 3: 614-620.

2. American Diabetes Association (2003). Gestational diabetes mellitus position statement. Diabetes Care, 26 (Suppl 1): S103-S105

3. Langer $\mathrm{O}$, Conway DL, Berkus MD, Xenakis EMJ \& Gonzales O (2000). A comparison of glyburide and insulin in women with gestational diabetes mellitus. New England Journal of Medicine, 343: 1134-1138.

4. Clarke M \& Oxman AD (1999). Cochrane Reviewers' Handbook 4.0 [updated July 1999]. In: Review Manager (RevMan) [Computer program]. Version 4.0. The Cochrane Collaboration, 1999. Oxford, England.

5. Coustan DR \& Lewis SB (1978). Insulin therapy for gestational diabetes. Obstetrics and Gynecology, 51: 306-310.

6. O'Sullivan JB \& Mahan CM (1980). Insulin treatment and high risk groups. Diabetes Care, 3: 482-485.
7. Persson B, Stangenberg M, Hansson U \& Nordlander E (1985). Comparative evaluation of two treatment regimens, diet versus insulin and diet. Diabetes, 34: 101-104.

8. Thompson DJ, Porter KB, Gunnells DJ, Wagner PC \& Spinnato JA (1990). Prophylactic insulin in the management of gestational diabetes. Obstetrics and Gynecology, 75: 960-964.

9. Buchanan TA, Kjos SL, Montoro MN, Wu PYK, Madrilejo NG, Gonzalez M, Nunez V, Pantoja PM \& Xiang A (1994). Use of fetal ultrasound to select metabolic therapy for pregnancies complicated by mild gestational diabetes. Diabetes Care, 17: 275-283.

10. Garner P, Okun N, Keely E, Wells G, Perkins S, Sylvain J \& Belcher J (1997). A randomized controlled trial of strict glycemic control and tertiary level obstetric care versus routine obstetric care in the management of gestational diabetes: a pilot study. American Journal of Obstetrics and Gynecology, 177: 190-195. 